\title{
Pengelolaan Modul IPA Terpadu Berbasis Metakognisi di SMP Muhammadiyah 06 Dau Malang
}

\author{
Yuni Pantiwati ${ }^{1 *}$, Fendy Hardian Permana ${ }^{2}$ \\ 1,2 Universitas Muhammadiyah Malang
}

\section{A R T I C L E I N F O}

Article history:

Received 10 December 2019

Received in revised form

01 January 2020

Accepted 30 January 2020

Available online 28

February 2020

Kata Kunci:

IPA, Modul, Terpadu

Keywords:

Science, Modules,

Integrated
A B S T R A K

Hasil observasi dan wawancara di SMP Muhammadiyah 06 Dau Malang menunjukkan bahwa bahar ajar yang ada dalam sekolah tersebut masih kurang bervariasi. Modul di sekolah kaidah penyusunan modul masih belum sesuai dengan ketentuan modul. Berdasarkan hal tersebut menunjukkan bahwa persoalan utama sekolah adalah guru di sekolah masih kurang motivasi dalam pengembangan modul. Kegiatan yang dilakukan adalah sosialisasi program pelatihan guru, pendampingan guru pre-tes, pembentukan tim IPA terpadu, penyusunan modul IPA terpadu, dan diseminasi best practices dengan kepala sekolah serta guru. Metode pendekatan penyelesaian permasalahan sekolah adalah pelatihan dan pendampingan penyusunan modul IPA terpadu serta dilakukannya diseminasi best practices kepada kepala sekolah dan guru. Modul yang dihasilkan 2 topik yaitu Lingkungan dan Energi. Peningkatan guru meningkat setelah pendampingan dan pelatihan jika dibandingkan dengan sebelumnya yag diukur melalui pre-tes dan pos-tes.

\section{A B S T R A C T}

The results of observations and interviews at SMP Muhammadiyah 06 Dau Malang showed that the teaching materials in the school were still less varied. Modules in school rules for the preparation of modules are still not in accordance with the provisions of the module. Based on this it shows that the main problem of schools is that teachers in schools are still lacking motivation in developing modules. The activities carried out were the socialization of teacher training programs, mentoring of pre-test teachers, formation of integrated science teams, preparation of integrated science modules, and dissemination of best practices with principals and teachers. The method for solving school problems is training and mentoring in the preparation of integrated science modules and disseminating best practices to school principals and teachers. The module produced 2 topics namely Environment and Energy. Teacher improvement increased after mentoring and training compared to before, measured through pre-tests and post-tests.

\footnotetext{
* Corresponding author.

E-mail addresses: fendy@umm.ac.id (Fendy Hardian Permana)
} 


\section{Pendahuluan}

Pendidikan merupakan kegiatan terencana yang berlangsung sepanjang hidup dan menjadi kebutuhan bagi manusia. Pendidikan tidak hanya berlangsung di sekolah, akan tetapi dapat juga berlangsung di dalam keluarga dan masyarakat. Oleh karena itu, pendidikan menjadi tanggung jawab bersama antara keluarga, masyarakat, dan juga pemerintah. Pendidikan memegang peranan penting bagi kehidupan manusia. Tanpa pendidikan manusia akan sulit berkembang atau bahkan tidak berkembang. Dengan demikian, pendidikan harus benarbenar diarahkan agar menghasilkan manusia yang berkembang dan berkualitas serta mampu bersaing, di samping memiliki akhlak dan moral yang baik.

Keberhasilan belajar peserta didik dipengaruhi oleh beberapa faktor, dapat berasal dari diri peserta didik sendiri maupun dari guru sebagai pendidik. Faktor yang berasal dari guru di antaranya kemampuan dalam merancang pembelajaran yang mampu menumbuhkan motivasi belajar peserta didik, menciptakan suasana belajar yang menarik dan menyenangkan. Namun pada kenyataannya, peserta didik masih menganggap matematika sebagai mata pelajaran yang menakutkan sehingga susah untuk dipahami. Hal ini terjadi karena pendidik belum mampu mengemas pembelajaran matematika menjadi lebih menyenangkan yang mampu menarik perhatian peserta didik. Sehingga membuat prestasi belajar peserta didik tidak sesuai dengan yang diharapkan.

Proses pembelajaran saat ini masih cenderung menempatkan guru sebagai pusat pembelajaran atau satu-satunya sumber belajar. Guru hanya sekedar memberikan pengetahuan kepada siswa. Siswa tidak diberikan kesempatan untuk membangun sendiri pengetahuan yang dimilikinya. Tentunya keadaan seperti itu berpengaruh pada hasil belajar siswa. Untuk itu perlu adanya perubahan dalam proses pembelajaran dimana dalam proses pembelajaran lebih diarahkan pada keaktifan siswa. Guru dapat memberikan kesempatan kepada siswa untuk membangun sendiri pengetahuan mereka serta guru bukan satu-satunya sebagai sumber belajar. Oleh karena itu, guru diharapkan mampu memilih model pembelajaran yang sesuai dengan materi pembelajaran agar diperoleh hasil belajar siswa yang baik (Ayuwanti, 2016).

Pendidikan adalah suatu sarana yang dapat mendukung sumber daya manusia dalam suatu Negara untuk dapat berkembang dan berdaya saing kuwat. Pendidikan bertujuan untuk menumbuhkan kompetensi-kompetensi yang dimiliki oleh peserta didik. Kompetensi tersebut dibutuhkan oleh peserta didik untuk dapat bersaing di masyarakat terutama di era globalisasi saat ini dimana persaingan semakin ketat.

Pendidikan akan dapat terlaksana dengan baik apabila didukung oleh sarana prasarana yang memadai dan mendukung proses pendidikan. Bahan ajar merupakan salah satu dari banyaknya hal yang mendukung terlaksananya proses pembelajaran dengan baik. Bahan ajar menjadi sesuatu yang penting dalam menunjang pendidikan karena bahan ajar berisi kumpulan informasi dan pengetahuanpengetahuan yang akan dipelajari oleh peserta didik. Bahan ajar membuat peserta didik mampu belajar dimana-mana dengan memanfaatkan bahan ajar tersebut. Bahan ajar yang dapat digunakan oleh peserta didik untuk belajar dan berlatih salah satunya adalah modul.

Modul merupakan sebuah buku yang bertujuan agar peserta didik dapat belajar secara mandiri tanpa atau dengan bimbingan guru. Hal tersebut seperti yang dinyatakan oleh Prastowo (2012) menyatakan bahwa modul adalah sebuah bahan ajar yang disusun secara sistematis dengan bahasa yang mudah dipahami peserta didik sesuai tingkat pengetahuan dan usia mereka agar mereka dapat belajar mandiri. Majid (2012) juga menyatakan bahwa modul adalah sebuah buku yang ditulis dengan tujuan agar siswa dapat belajar mandiri atau tanpa bantuan guru. BPPK (2009) menyatakan modul adalah salah satu bahan ajar cetak yang memiliki beberapa kelebihan dibandingkan dengan bahan ajar cetak lainnya.

Modul akan sangat membantu proses pembelajaran terutama melatih kompetensi peserta didik, seperti yang dinyatakan oleh Hamdani (2011) guru dapat mencegah kejenuhan belajar pada peserta didik dengan mengembangkan bahan ajar, salah satunya adalah bahan ajar dalam bentuk cetak seperti modul. Menurut (Wenno, 2010) modul sangat bermanfaat bagi guru dalam menyampaikan materi kepada peserta didik, karena siswa akan lebih kreatif dalam mengembangkan dirinya, kegiatan pembelajaran menjadi lebih menarik, peserta didik lebih banyak mendapat kesempatan belajar mandiri, mengurangi ketergantungan terhadap kehadiran guru, dan peserta didik juga akan mendapat kemudahan dalam mempelajari tiap kompetensi.

Menurut Santyasa (2008), secara prinsip tujuan pembelajaran adalah agar siswa berhasil menguasai bahan pelajaran sesuai dengan indikator yang telah ditetapkan. Hal ini disebabkan karena di dalam kelas berkumpul siswa dengan kemampuan yang berbeda-beda (kecerdasan, bakat, dan kecepatan belajar) maka perlu diadakan pengorganisasian materi, sehingga semua siswa dapat mencapai dan menguasai materi pelajaran sesuai dengan tujuan yang telah ditetapkan dalam waktu yang disediakan. Disamping pengorganisasian materi pembelajaran, juga perlu memperhatikan cara-cara mengajar yang 
disesuaikan dengan pribadi individu. Bentuk pelaksanaan cara mengajar tersebut adalah dengan membagi-bagi bahan pembelajaran menjadi unit-unit pembelajaran yang masing-masing bagian meliputi satu atau beberapa pokok bahasan. Bagian-bagian materi pembelajaran tersebut disebut modul. Berdasarkan beberapa pengertian modul di atas maka dapat disimpulkan bahwa modul pembelajaran adalah salah satu bentuk bahan ajar yang dikemas secara sistematis dan menarik sehingga mudah untuk dipelajari secara mandiri. Penggunaan modul sebagai fasilitas atau sumber belajar telah banyak diterapkan dan dikembangkan, dengan tujuan a) mempersingkat waktu yang diperlukan oleh siswa untuk menguasai tugas pelajaran tersebut; dan b)menyediakan waktu sebanyak yang diperlukan oleh siswa dalam batas-batas yang dimungkinkan untuk menyelenggarakan pendidikan yang teratur.

Modul pembelajaran merupakan salah satu bahan belajar yang dapat dimanfaatkan oleh siswa secara mandiri. Modul yang baik harus disusun secara sistematis, menarik, dan jelas. Modul dapat digunakan kapanpun dan dimanapun sesuai dengan kebutuhan siswa. Anwar (2010), menyatakan bahwa modul adalah bahan ajar yang disusun secara sistematis dan menarik yang mencakup isi materi, metode dan evaluasi yang dapat digunakan secara mandiri untuk mencapai kompetensi yang diharapkan dengan karakteristik modul pembelajaran sebagai berikut: 1) Self instructional, siswa mampu membelajarkan diri sendiri, tidak tergantung pada pihak lain; 2) Self contained, seluruh materi pembelajaran dari satu unit kompetensi yang dipelajari terdapat didalam satu modul utuh; 3) Stand alone, modul yang dikembangkan tidak tergantung pada media lain atau tidak harus digunakan bersama-sama dengan media lain; 4) Adaptif, modul hendaknya memiliki daya adaptif yang tinggi terhadap perkembangan ilmu dan teknologi; 5) User friendly, modul hendaknya juga memenuhi kaidah akrab bersahabat/akrab dengan pemakainya; 6) Konsistensi, konsisten dalam penggunaan font, spasi, dan tata letak (S. Sirate, 2017).

IPA merupakan pengetahuan yang sistematis dan tersusun secara teratur, berlaku umum (universal), dan berupa kumpulan data hasil observasi dan eksperimen (Carin dan Sund, 1993). Proses memahami IPA untuk menemukan suatu konsep melalui tahaptahap ilmiah atau dapat dikatakan metode ilmiah, sehingga metode ilmiah merupakan salah satu ciri dari ilmu pengetahuan alam. Proses metode ilmiah harus mencerminkan sifat sistematis, konsisten, dan objektif. Metode ilmiah merujuk pada teknikteknik investigasi atas suatu atau beberapa fenomena atau gejala, memperoleh pengetahuan baru, atau mengoreksi dan memadukan pengetahuan sebelumnya. Metode pencarian (method of inquiry) dapat disebut ilmiah, jika berbasis pada bukti-bukti dari objek yang dapat di observasi, empiris, dan terukur dengan prinsip-prinsip penalaran yang spesifik (Lestari, 2015).

Pembelajaran IPA bukan hanya untuk menguasai sejumlah pengetahuan sebagai produk IPA, tetapi juga harus menyediakan ruang yang cukup untuk tumbuh berkembangnya sikap ilmiah, berlatih proses pemecahan masalah, dan penerapan IPA dalam kehidupan nyata. Pembelajaran IPA yang diterapkan guru di sekolah saat ini cenderung siswa hanya mempelajari IPA sebagai produk, menghafal konsep, prinsip, hukum, dan teori. Keadaan ini diperparah oleh pembelajaran yang berorentasi pada tes/ujian. Hakekat IPA sebagai sikap, proses, dan aplikasi tidak muncul dalam pembelajaran, hal ini disinyalir menjadi penyebab rendahnya kualitas pendidikan di Indonesia. Rendahnya kualitas pendidikan sains di Indonesia diantaranya terlihat dari hasil survei yang dilakukan oleh PISA (Programme for International Student Assessment) pada tahun 2012. Dari total 65 negara dan wilayah yang masuk survei PISA, Indonesia berada di urutan 64 untuk bidang sains, hanya lebih tinggi satu peringkat dari Peru. Survei PISA diikuti oleh negara-negara yang tergabung dalam The Organisation for Economic Co-operation and Development (OECD). PISA menguji kemampuan siswa di tiga bidang yaitu matematika, membaca, dan sains. PISA 2012, diikuti oleh lebih dari 510.000 siswa usia 15 tahun di 65 negara dan wilayah (NCES, 2014). Peraturan Menteri Pendidikan dan Kebudayaan Republik Indonesia Nomor 65 Tahun 2013 Tentang Standar Proses diharapkan, proses pembelajaran pada satuan pendidikan diselenggarakan secara interaktif, inspiratif, menyenangkan, menantang, memotivasi peserta didik, untuk berpartisipasi aktif, serta memberi ruang yang cukup bagi prakarsa, kreativitas, dan kemandirian sesuai dengan bakat, minat, dan perkembangan fisik serta psikologis peserta didik. Prinsip pembelajaran kurikulum 2013 yang digunakan sebagai berikut: 1) peserta didik diberitahu menuju peserta didik mencari tahu; 2) guru menjadi satu-satunya sumber belajar menjadi belajar berbasis aneka sumber belajar; 3) pembelajaran yang menekankan jawaban tunggal menuju pembelajaran dengan jawaban yang kebenaranya multi demensi; 4) pembelajaran verbalisme menuju keterampilan aplikatif; 5) peningkatan dan keseimbangan antara keterampilan fisikal dan keterampilan mental; 6) pembelajaran yang berlangsung di rumah, di sekolah, dan di masyarakat; 7) pembelajaran yang menerapkan nilai-nilai dengan memberi keteladanan (ing ngarso sung tulodo), membangun kemauan (ing madyo mangun karso), dan mengembangkan kreativitas peserta didik dalam proses pembelajaran (tut wuri handayani) (Sudarno, 2015).

Hasil penelitian dari Khaerun dkk (2010) menunjukkan bahwa pembelajaran dengan modul dapat meningkatkan hasil belajar karena perbandingan antara hasil belajar peserta didik dengan menggunakan modul pembelajaran mengalami peningkatan yang lebih baik. Hasil penelitian Muhafid dkk (2013) 
menunjukkan bahwa modul ipa terpadu berpendekatan keterampilan proses dapat mengembangkan keterampilan peserta didik.

Hasil observasi dan wawancara di SMP Muhammadiyah 06 Dau Malang menunjukkan bahwa bahar ajar yang ada dalam sekolah tersebut masih kurang bervariasi, bahan ajar yang paling banyak ditemukan adalah buku teks dan LKS. Modul di sekolah tersebut ditemukan tetapi unsur dan kaidah penyusunan modul masih belum sesuai dengan ketentuan modul, terutama modul IPA terpadu. Wawancara dengan guru IPA di sekolah juga menyatakan bahwa guru mengalami kesulitan dalam mengembangkan modul yang baik dan benar. Berdasarkan hal tersebut menunjukkan bahwa persoalan utama/prioritas sekolah tersebut (mitra) adalah guru di sekolah masih kurang motivasi dalam pengembangan modul untuk mendukung kegiatan pembelajaran dan guru juga masih minim informasi terkait dengan penyusunan dan pengembangan modul yang benar. Hal tersebut sesuai dengan pernyataan Muhafid dkk (2013) menyatakan bahwa variasi bahan ajar yang sekarang ada di sekolah-sekolah hanya buku teks dan LKS.

SMP Muhammadiyah 06 Dau Malang adalah sekolah yang terletak di Jl Margo Basuki No 48 Mulyoagung, Dau, Malang. Sekolah ini menjadi sangat berpotensi dan berpeluang untuk dilakukan kegiatan pengabdian penyusunan dan pengembangan modul IPA dikarenakan disekolah tersebut yang menjadi prioritas utama sekolah (mitra) adalah permasalahan minimnya ketersediaan modul dan kurangnya informasi terkait pengembangan modul yang baik. Potensi yang lain adalah kepala sekolah beserta semua anggota sekolah mendukung adanya kegiatan program pengabdian terkait dengan pengelolaan modul IPA terpadu, selain itu guru bersemangat untuk mengikuti kegiatan pendampingan tersebut menjadi potensi yang utama. Pihak sekolah juga menyampaikan kepada tim pengabdian bahwa pihak sekolah menginginkan dan mengizinkan kegiatan tersebut untuk dilakukan di sekolah.

Berdasarkan hal tersebut maka perlu dilakukan kegiatan pendampingan pengelolaan modul IPA terpadu di SMP Muhammadiyah 06 Dau Malang. Kegiatan pengabdian ini tentunya adalah untuk mendukung kemajuan proses pembelajaran di sekolah dengan memberikan bekal kompetensi pengembangan modul IPA yang baik dan benar sesuai dengan ketentuan yang berlaku, seperti yang dinyatakan Rosyidah dkk (2013) bahwa pengembangan dan penyusunan modul harus memperhatikan komponen-komponen yang dikeluarkan oleh BSNP meliputi komponen kelayakan isi, penyajian, kegrafikan, dan kebahasaan. Pihak tim pengabdian dengan sekolah sudah bersepakat bekerjasama untuk mengadakan kegiatan tersebut di sekolah.

\section{Metode}

Metode pendekatan yang akan digunakan dalam menyelesaikan permasalahan sekolah tersebut adalah berupa pelatihan dan pendampingan penyusunan modul IPA terpadu serta dilakukannya diseminasi best practices dengan kepala sekolah dan guru. Secara lebih detail kegiatan pendekatan penyelesaian permasalahan ini dan partisipasi mitra dalam pelaksanaan program dapat dilihat pada Tabel 1 .

Tabel 1. Kegiatan pelatihan dan pendampingan

\begin{tabular}{lll}
\hline No & Kegiatan & Partisipasi Mitra \\
\hline 1 & $\begin{array}{l}\text { Pelatihan guru penyampaian materi pengantar dan } \\
\text { penyamaan persepsi }\end{array}$ & Diskusi dan sosialisasi \\
\hline 2 & Diskusi dan sharing pengalaman terkait dengan: & Diskusi, pelatihan, workshop \\
a) Konsep Dasar IPA Terpadu & \\
b) Pembentukan Tim Guru IPA Terpadu & \\
c) Refleksi Keterlaksanaan Pembelajaran IPA & \\
d) Sosialisasi Penyusunan Modul IPA Terpadu & \\
\hline 3 & Pendampingan Penyusunan Modul & Praktek, diskusi, evaluasi \\
\hline 4 & Diseminasi best practices dengan guru-guru lainnya & Praktek, diskusi, evaluasi \\
\hline
\end{tabular}

Rencana kegiatan berupa langkah-langkah solusi (target kegiatan dan instrument pengukuran ketercapaian) menyelesaikan permasalahan sekolah dapat dilihat pada Tabel 2.

Tabel 2. Rencana kegiatan pelatihan dan pendampingan

\begin{tabular}{cccc}
\hline Target Kegiatan & Kegiatan & Subyek \& Metode & $\begin{array}{c}\text { Instrumen pengukuran } \\
\text { ketercapaian }\end{array}$ \\
\hline Pelaksanaan program & Sosialisasi program & Warga sekolah: & Peningkatan \\
\hline
\end{tabular}




\begin{tabular}{llll}
\hline $\begin{array}{l}\text { penyusunan Modul IPA } \\
\text { Terpadu }\end{array}$ & $\begin{array}{l}\text { Pelatihan guru } \\
\text { Pendampingan guru } \\
\text { Pre-tes }\end{array}$ & $\begin{array}{l}\text { Ceramah, Diskusi } \\
\text { Pendampingan }\end{array}$ & $\begin{array}{l}\text { pengetahuan guru IPA } \\
\text { tentang Sumber Belajar } \\
\text { (Modul) IPA Terpadu }\end{array}$ \\
\hline $\begin{array}{l}\text { Pembentukan Tim IPA } \\
\text { Terpadu }\end{array}$ & $\begin{array}{l}\text { Pembentukan Tim IPA } \\
\text { Terpadu }\end{array}$ & $\begin{array}{l}\text { Kepala Sekolah dan } \\
\text { guru: musyawarah }\end{array}$ & $\begin{array}{l}\text { Terbentuknya TIM } \\
\text { Guru IPA Terpadu }\end{array}$ \\
\hline $\begin{array}{l}\text { Penyusunan Modul IPA } \\
\text { Terpadu }\end{array}$ & $\begin{array}{l}\text { Penyusunan Modul IPA } \\
\text { Terpadu }\end{array}$ & $\begin{array}{l}\text { Warga sekolah: } \\
\text { Ceramah, Diskusi, } \\
\text { pelatihan, }\end{array}$ & $\begin{array}{l}\text { Terwujudnya Modul } \\
\text { IPA Terpadu }\end{array}$ \\
& & Pendampingan & \\
\hline Diseminasi best practices & dengan Kepala sekolah, guru & Terselenggaraannya \\
& & Desiminasi \\
\hline
\end{tabular}

\section{Hasil dan pembahasan}

Kegiatan pengabdian pengelolaan modul IPA terpadu di SMP Muhammadiyah 6 Dau Malang tersebut tim pelaksana PkM memberikan pelatihan pada guru IPA, dimana dalam kegiatan tersebut diawali dengan kegiatan penyamaan persepsi dan pemberian materi pengantar terkait modul IPA. Kemudian dilanjutkan dengan hal-hal yang lebih teknis terkait penyusunan dan pengembangan modul IPA: a) Konsep Dasar IPA Terpadu, b) Pembentukan Tim Guru IPA Terpadu, c) Refleksi Keterlaksanaan Pembelajaran IPA, d) Sosialisasi Penyusunan Modul IPA Terpadu.

Kegiatan pengabdian ini memiliki 5 target kegiatan yaitu pelaksanaan program penyusunan modul IPA terpadu, pembentukan tim IPA terpadu, penyusunan modul IPA terpadu, dan diseminasi. Pada target kegiatan pertama yaitu pelaksanaan program penyusunan modul IPA terpadu berjalan dengan lancar. Kegiatan yang dilakukan adalah tim peneliti melakukan kegiatan sosialisasi program, pelatihan guru, pendampinagn guru, dan pretes. Peserta yang hadir dalam kegiatan pertama adalah warga sekolah (kepala sekolah dan semua guru-guru di sekolah). Prosedur yang dilakukan oleh peneliti adalah dengan cara ceramah, diskusi, dan penampingan. Sosialisasi program yang dilakukan adalah peneliti menerangkan terkait dengan modul IPA, pentingnya modul IPA, dan bagaimana pengembangan modul IPA. Setelah sosialisasi dilakukan, kemudian dilakukan pelatihan dan pendampingan kepada guru untuk mengembangkan modul IPA sesuai dengan aturan. Kemudian dilakukan pretes kepada guru. Hasil yang didapat adalah terdapat peningkatan pengetahuan guru IPA tentang sumber belajar IPA terpadu. Kegiatan tersebut dapat dilihat pada Gambar 1.

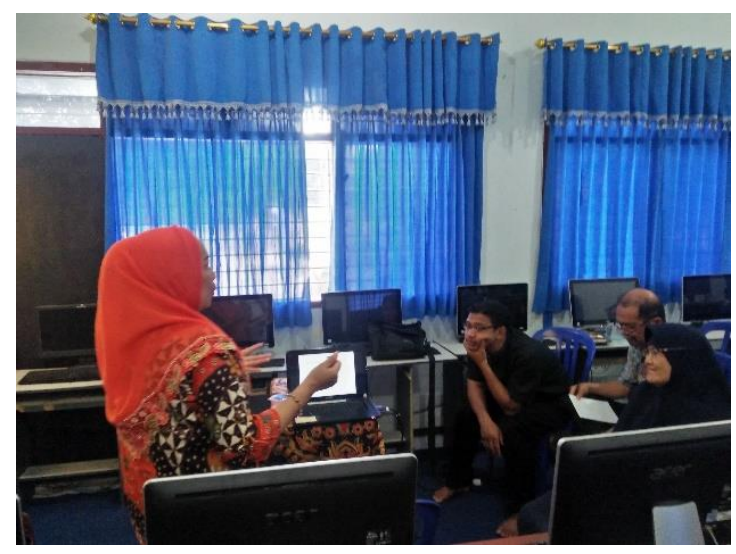

Gambar 1. Kegiatan Sosialisasi dan Pendampingan dalam Penyusunan serta Pengembangan Modul IPA.

Pada target kegiatan kedua yaitu pembentukan tim IPA terpadu. Kegiatan pembentukan tim IPA terpadu ini diikuti oleh tim peneliti, kepala sekolah, dan guru IPA di sekolah tersebut. Cara yang dilakukan adalah dengan musyawarah kepada kepala sekolah dan guru-guru. Hasil yang didapat dari kegiatan ini adalah terbentuknya tim guru IPA terpadu. Nantinya tim ini akan menangani pengembangan mata pelajaran IPA terpadu di sekolah tersebut termasuk dalam hal pengembangan modul IPA. 


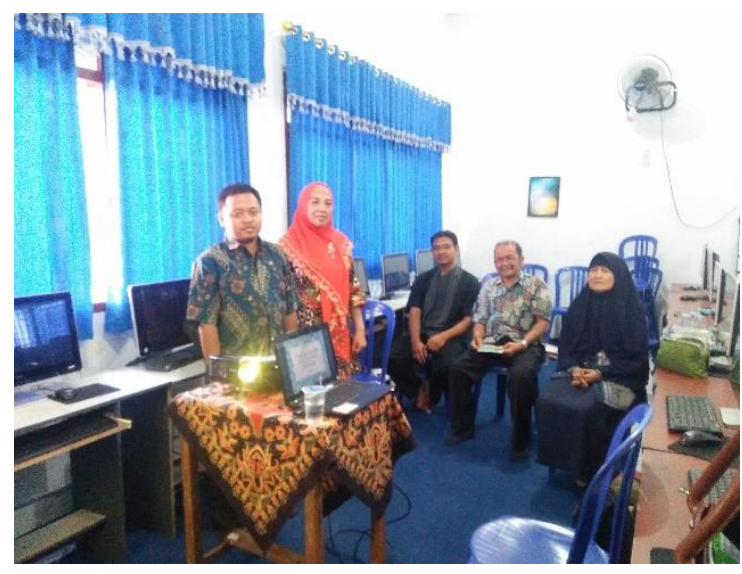

Gambar 2. Pembentukan tim IPA terpadu

Pada target kegiatan ketiga adalah penyusunan modul IPA terpadu. Pada tahap ini guru tim IPA terpadu tersebut merancang dan menyusun modul IPA terpadu dibantu dengan diarahkan oleh tim peneliti. Tim peneliti mengarahkan para tim guru IPA dalam menyusun modul IPA dengan cara ceramah, diskusi, pelatihan, dan pendampingan. Hasil yang didapat adalah terwujudnya modul IPA terpadu.

Pada target kegiatan keempat adalah dilakukan diseminasi dengan kepala sekolah dan guru. Diseminasi ini dihadiri oleh kepala sekolah dan guru-guru di sekolah, sebagai contoh dalam pengembangan modul yang baik.

\section{Simpulan dan saran}

Kegiatan pengabdian pengelolaan modul IPA terpadu di SMP Muhammadiyah 6 Dau Malang sangat berperan dalam meningkatkan kualitas kegiatan pembelajaran di sekolah tersebut, karena tim IPA terpadu telah mngembangkan modul IPA yang baik. Modul IPA yang telah dikembangkan memberikan inspirasi kepada semua guru di sekolah untuk ikut juga mengembangkan modul guna pembelajaran yang baik di sekolah.

\section{Daftar Rujukan}

Ayuwanti, Irma. 2016. Meningkatkan Aktivitas Dan Hasil Belajar Matematika Menggunakan Model Pembelajaran Kooperatif Tipe Group Investigation Di Smk Tuma'ninah Yasin Metro . Jurnal SAP Vol. 1 No. 2 Desember 2016

BPPK. 2009. Pedoman penulisan modul diklat keuangan. Jakarta: BPPK

Hamdani. 2011. Strategi belajar mengajar. Bandung: Pustaka Setia

Khaerun, I. R., Samsudi \& Murdani. 2010. Kefektifan penggunaan modul pembelajaran interaktif belajar kompetensi bahan bakar bensin. Jurnal Pendidikan Teknik Mesin, 10(1) : 1.

Lestari . 2015. Pengembangan Modul Ipa Terpadu Dengan Pendekatan Saintifik Tema Sampah Untuk Kelas Vii Smp/Mts . Jurnal Inkuiri Vol 4, No. 2, 2015.

Majid, A. 2012. Perencanaan pembelajaran. Bandung: PT Remaja Rosdakarya

Mardiani, E., \& Noerhodijah, S.R. 2015. Penyusunan modul pembelajaran jaringan tumbuhan berbasis hakikat sains. Biodidaktika, volume 10 no 2, ISSN: 1907-087X.

Muhafid, E. A., Dewi, N. R., \& Widiyatmoko, A. 2013. Pengembangan modul IPA terpadu berpendekatan keterampilan proses pada tema bunyi di SMP kelas VIII. Unnes Science Education Journal, Vol 2, No 1.

Pistanty, M.A., Sunarno, W., \& Maridi. 2015. Pengembangan modul IPA berbasis problem based learning untuk meningkatkan kemampuan memecahkan masalah pada materi polusi serta dampaknya pada 
manusia dan lingkungan siswa kelas XI pancasila purwodadi. Jurnal Inkuiri, vol 4, no 2, hal 68-75, ISSN: 2252-7893.

Prastowo, A. 2012. Panduan kreatif membuat bahan ajar inovatif. Jogjakarta: DIVA Press

Rosyidah, A. N., Sudarmin, \& Siadi, K. 2013. Pengembangan modul IPA berbasis etnosains zat aditif dalam bahan makanan untuk kelas VIII SMP Negeri 1 Pegandon Kendal. Unnes Science Education Journal, Vol 2, No 1 .

Sudarno. 2015. Pengembangan Modul Ipa Terpadu Berbasis Kontekstual Dengan Tema Pembuatan Tahu Kelas Vii Smp Negeri 2 Jatiyoso . Jurnal Inkuiri Vol 4, No. 3, 2015

S. Sirate, Sitti Fatimah. 2017. Pengembangan Modul Pembelajaran Berbasis Keterampilan Literasi . Journal of Educational Communication Volume VI, Nomor 2, Juli - Desember 2017

Wenno, I. H. 2010. Pengembangan Model Modul IPA Berbasis Problem Solving Method Berdasarkan Karakteristik Siswa dalam Pembelajaran di SMP/MTs. Jurnal Cakrawala Pendidikan, No 2. 